\title{
Breast Cancer cN2b TNM Finding v6
}

National Cancer Institute

\section{Source}

National Cancer Institute. Breast Cancer cN2b TNM Finding v6. NCI Thesaurus. Code C73351.

Breast cancer with metastasis only in clinically apparent ipsilateral internal mammary nodes and in the absence of clinically evident axillary lymph node metastasis. (from AJCC 6th Ed.) 